УдК : 070: 327

\title{
МОДЕЛЬ ЗАСОБІВ МАСОВОЇ КОМУНІКАЦІЇ (НАЦІОНАЛЬНОЇ ЖУРНАЛІСТИКИ) У КІБЕРПРОСТОРІ: БЕЗПЕКА ОСОБИ, СУСПІЛЬСТВА, ДЕРЖАВИ
}

Павлюх Марія Василівна

кандидат наук із соціальних комунікацій, Національний університет «Львівська політехніка», м. Львів, Україна ORCID:0000-0001-5502-8367

mariapavluch1982@gmail.com
Надіслано:

03.01.2020

Рецензовано: 14.01.2020

Прийнято: 29.01.2020

Головний об’єкт дослідження - засоби масової комунікації (журналістика) українського інформаційного кіберпростору. Проаналізовано багатий фактаж досліджень із масової комунікації. Здійснено огляд важливих праць, які демонструють розвиток національного інформаційного кіберпростору України. Розглянуто важливі особисті критерії журналіста, які повинні стати основою ефективної моделі Засобів масової комунікації (національної журналістики) у сучасному інтернет-просторі. У дослідженні використано комплекс загальних і спеціальних методів:метод концептуального аналізу у визначенні базових характеристик масової комунікації, компаративний аналіз (у зіставленні та протиставлення моделей засобів масової комунікації, зокрема журналістики), функціональний аналіз ( з'ясуванні ролі та базових функцій Засобів масової комунікації, зокрема журналістики).

Засоби масової комунікації, зокрема національна журналістика впливають на безпеку особи, суспільства та української нації. В умовах російської агресії важливо, щоб модель національної журналістики була ефективною для безпеки українського інформаційного простору. Важливо, щоб національна політика сприяла інформаційній безпеці української нації, а модель Засобів масової комунікації, зокрема національної журналістики, були дієвим механізмом у боротьбі з російським агресором.

Ключові слова: безпека; кіберпростір; національна модель; засоби масової комунікації; журналістика; публіцистика; інформаційна війна; фейки. 
Pavlyuh Mariia, Ph.D. in Social Communication, Lviv Polytechnic National University, Lviv, Ukraine

Model of Mass-Communication (National Journalism) in Cyber Space:

Personal Security, Societies, States

The main object of study is the mass communication (journalism) of the Ukrainian cyberspace. The rich fact of mass communication research has been analyzed. An overview of important works demonstrating the development of Ukraine's national cyberspace has been carried out. The important personal criteria of a journalist are considered, which should become the basis of an effective model of mass communication (national journalism) in the modern Internet space.

The study used a set of general and specific methods: a conceptual analysis method in determining the basic characteristics of mass communication, comparative analysis (in comparing and contrasting models of mass media, including journalism), functional analysis (in clarifying the role and basic functions of mass media, including journalism).

Mass media, including national journalism, influence the security of the individual, society and the Ukrainian nation. In the face of Russian aggression, it is important that the model of national journalism be effective for the security of the Ukrainian information space. It is important for national politics to promote the information security of the Ukrainian nation, and that the mass media model, in particular, national journalism, be an effective mechanism in the fight against the Russian aggressor.

Key words: security; cyberspace; national model; mass media; journalism; journalism; information war; fakes.

Павлюх Мария Васильевна, кандидат наук по социальным коммуникациям, Национальный университет "Львовская политехника», г. Львов, Украина

Модель средств массовой коммуникации (национальной журналистики) в киберпространстве:

\section{Безопасность человека, общества, государства}

Главный объект исследования - Средства массовой коммуникации (журналистика) украинского информационного киберпространства. Проанализированы богатый фактаж исследований по массовой коммуникации. Осуществлен обзор важных работ, которые демонстрируют развитие национального информационного киберпространства Украины. Рассмотрены важные личные критерии журналиста, которые должны стать основой эффективной модели Средств массовой коммуникации (национальной журналистики) в современном интернет-пространстве. В исследовании использован комплекс общих и специальных методов: метод концептуального 
анализа в определении базовых характеристик массовой коммуникации, компаративный анализ (в сопоставлении и противопоставлении моделей Средств массовой коммуникации, в частности журналистики), функциональный анализ (в выяснении роли и базовых функций Средств массовой коммуникации, в частности журналистики).

Средства массовой коммуникации, в частности национальная журналистика влияют на безопасность личности, общества и украинской нации. В условиях российской агрессии важно, чтобы модель национальной журналистики была эффективной для безопасности украинского информационного пространства. Важно, чтобы национальная политика способствовала информационной безопасности украинской нации, а модель Средств массовой коммуникации, в частности национальной журналистики, были действенным механизмом в борьбе с российским агрессором.

Ключевые слова: безопасность; киберпространство; национальная модель; Средства массовой коммуникации; журналистика; публицистика; информационная война; фейки.

\section{Вступ}

Розвиток інтернет-технологій у світі, що відбувається шаленими темпами сьогодні має позитивні та негативні сторони. Серед позитивних сторін: економія часу, грошей; зручність; простота використання інтернеттехнологій та ін. Поряд з тим, інтернет-технології мають негативні сторони, які погано впливають на особу, суспільство та державу. Безпека особистості залежить від іï рівня знань та правильного використання часу та інформаційних ресурсів. Безпека суспільства та безпека держави часто стикається із проблемою кібербезпеки у віртуальному просторі.

Кібератаки національних інформаційних ресурсів $\epsilon$ елементами психологічної та інформаційної війни. Унаслідок російсько-української війни, кібератаки на національні ресурси стали відбуватися часто. Захист, безпека національного простору залежить від безпеки особистості у віртуальній реальності. Використання і популярність соціальних мереж можуть становити національну загрозу, оскільки російські хакери використовують особисті дані у своїй пропаганді. Особисті дані, які особа поширює через мережу не мають високого рівня захисту. Поряд з тим, Мережа може поширювати неправдиві відомості, фейки та багато недостовірної інформації 3 метою маніпуляції громадською думкою.

Важливу роль для безпеки суспільства та держави відіграють Засоби масової комунікації (ЗМК), зокрема національна Інтернет-журналістика. Традиції, які склалися навколо національних ЗМК не завжди гарантують безпеку для особи і користувача Мережі. Захист національної безпеки залежить 
від особистої безпеки, а також інформаційної, носієм якої $\epsilon$ інтернетжурналістика. Тому важливо сформувати модель національної інтернетжурналістики для безпеки у кіберпросторі.

У час шаленого розвитку техніки та комунікації, зокрема Інтернету (ЗМК) перед дослідниками постають питання: наскільки безпечна для держави, людини, суспільства віртуальна реальність; які моральні норми слід застосовувати журналістам, які працюють в Інтернет-журналістиці; які загрози чатують на користувача соціальних мереж? Сьогодні сучасна людина не бачить свого життя без спілкування у «Фейсбуці», «Контактах», чатах, тобто віртуальній реальності. Поряд 3 тим, що віртуальна реальність дає багато можливостей, стираючи межі між простором, віртуальна реальність $є$ великою загрозою для особистісної безпеки людини і безпеки інформаційного простору нації. Чому ж маса, масове спілкування таке важливе і небезпечне водночас? Як поєднати націогенез, віртуальну реальність та масову комунікацію? Яка національна модель ЗМК дієва і чому вони важливі для безпеки суспільства, особи, нації? Проаналізуймо праці дослідників Засобів масової комунікації.

\section{Аналіз останніх досліджень і публікацій}

Серед важливих досліджень масової комунікації значне місце займає вивчення глобалізації та масової комунікації; Інтернету та масової комунікації. Це праці таких вчених: С. Квіта («Масові комунікації»), стаття І. Карпи, М. Павлюх («Інтернет: небезпечна віртуальна реальність»), О. Колісник («Інтернет-журналістика у світлі медіа-досліджень»), О.Зернецької («Глобальний розвиток систем масової комунікації...)), Г. Маркової («Масова комунікація в умовах глобалізації...»). Представник Києво-могилянської школи С. Квіт розглядає масову комунікацію у контексті глобалізаційних процесів. Автор виокремлює кілька американських підходів у вивченні журналістики, ї̈ головні функції (контроль медіа владою та іншими силами), вводить поняття «комунікаційного хаосу у нелінійній системі світу» (Kvit, 2008). Важко не погодитися з думкою С. Квіта, що журналістика обслуговує тоталітарні режими, а незалежні медіа можливі тільки при бажанні нації. Інтерактивність С. Квіт розуміє як багатосторонній інформаційний обмін з користувачем, з окремими представниками та усією аудиторію.

Думки О.Зернецької у праці «Процеси глобалізації й трансформації систем масової комунікації» змушують нас надалі говорити не тільки про існування інформаційної індустрії, а й індустрії масової комунікації - індустрії впливу на людину, суспільство й цивілізацію» (Zernetska, O.V). Г. Маркова виокремлює кілька головних аспектів глобалізації, серед яких комунікаційні імперії, транснаціоналізація масової культури, технологічні імперативи, горизонтальна інтеграція комунікативної індустрії, технологічна конвергенція 
між різними секторами комунікаційних індустрій. Важко не погодитись із дослідницею, яка розуміє глобалізацію як світовий контекст, у якому формується національна інфраструктура (Markova, 2007, p. 336).

Теорія мас та еліти (С. Вовканич), бунт мас (Х. Ортега-і-Гасет) не завжди пов'язані тільки з механізмами активності, взаємовпливів політики і ЗМI. Маси і масове спілкування набирають нових форм і тісно пов'язані із націогенезом та поняттям «нація». Прикладами особливого націодуховного виду масового спілкування виступають: «Революція на граніті» та «Помаранчева революція», в яких був задіяний компонент націотворення і духовності. Старими націями керує Провидіння (духовний чинник) і нація - формація трансцендентальна, понадчасова (дефініція - М.П.). Подібні ідеї висловлюють В.Буряк та В.Демченко - представники дніпровської наукової школи. В. Демченко узагальнює теорії масової комунікації українських вчених, ділить їх на наукові школи, розвиває думку про глобалізацію та національну ідентичність, слушно вводить поняття глобалізації масової комунікації, глобалізації як мегаявища, як конвергенцію національних ЗМК та націоналізацію інформаційного простору, тобто «націоглобалізацію». В. Буряк розглядає масову комунікацію як соціальну реалізацію інформації, виокремлює текст як важливу структурну одиницю масової комунікації (Buriak, 2009, р. 2). Для цього застосований термін «інформаційна сутність комунікації» - первинна, форма її інтерпретації (текст) - вторинна. Текст - це продукт спілкування, що володіє певною самостійністю як засіб впливу на аудиторію.

\section{Формулювання мети і завдань статті}

Досліджуючи праці вчених про безпеку суспільства, особи, нації з'ясувати роль національної моделі ЗМК (національної журналістики) уінформаційному просторі; відобразити взаємозалежність національної журналістики, глобалізації та кібербезпеки. Мета передбачає такі завдання:

- здійснити огляд важливих досліджень із масової комунікації та Інтернет-простору, Інтернет-журналістики;

- проаналізувати соціокомунікативні моделі журналістики, та з'ясувати, які з них сьогодні переважають;

- встановити взаємозалежність кібербезпеки та журналістики у національних масштабах;

- сформувати свою модель національних ЗМК (національної журналістики), яка буде ефективною для безпеки українців та держави.

\section{Виклад основного матеріалу дослідження}

Сьогодні популярні дослідження Інтернету і систем масової комунікації. Маємо ставлення до віртуальної реальності: позитивне, коли дослідники намагаються віртуальну реальність і електронні ЗМК розглядати як потужний людський індустріальний розвиток, розвиток масової комунікації, створення 
блогосистем (Kolesnik, 2010), та негативний, коли дослідники вбачають увіртуальній реальності загрозу людській психіці, тобто етичний аспект віртуалізації (Pavlyukh, 2002). О. Колісник розглядає блогосферу як соціальну мережу (Kolesnik, 2010, p. 122), важливе середовище для вивчення суспільної думки, блог визначається повноцінним та автономним різновидом журналістської діяльності. Наша позиція збігається із однойменною статтею, названою вище і охоплює аспект етичності процесів віртуалізації (Pavlyukh, 2002). І. Карпа досліджує мову та ефективність інтерактивної комунікації. Інтерактивна комунікація подана як нелінійний, екстрадинамічний, багатовекторний процес спілкування гіпертекстуального середовища, опосередкований високотехнологічними засобами передачі даних та доступу до них (Karpa, 2009, р. 193]. Важливим в аналізі систем масової комунікації виступає пресупозиція або підтекст. Нашому дослідженню близька третя структура комунікації, коли від мовця залежить ефективність комунікаційного процесу.

Особливе місце серед джерел вивчення масової комунікації займає дослідження київського науковця Г. Почепцова «Теорія комунікації», яка розкриває комунікацію як цивілізаційний феномен. Цікавий у дослідженні розгляд масової комунікації з точки зору паблік рилейшнз, пропаганди, реклами. Серед комунікативних моделей Г. Почепцов досліджує психоаналіз, групову терапію, нейролінгвістичне програмування (Pocheptsov, 2001). Аргументовану, іміджеву і пропагандивну комунікації автор виокремлює у різні види комунікації. Г. Почепцов перший в Україні описував механізм інформаційної війни (розділ в книзі). Велику увагу автор звертає на психологічні та пропагандивні війни. Автор дослідив міфологічну, художню, перформансну комунікації. Праця Г. Почепцова - синкретичне дослідження, в якому автор вводить ключові компоненти масової комунікації: цільова аудиторія, канал, метакомунікативні знання, контекст.

М. Житарюк, аналізуючи соціокультурні моделі журналістики як i $€$ Прохоров та Є. Ахмадулін, розглядає їі як «складну соціальну систему не просто суспільний, політичний, культурний, державотворчий, державозміцнюючий, плюралістичний та демократично-ціннісний феномен, а насамперед соціокультурний адекват дійсності (3 усіма вадами та досягненнями), який функціонує за правилами соціокультурної моделі» (Zhytaryuk, 2008, p. 48), запроваджує поняття «соціокультурного адеквату дійсності», розглядає журналістику як живий організм, соціокультурний феномен, складний, універсальний механізм. Цікаво у дослідника подана первинна та вторинна модель віртуалізації. Вторинна модель віртуалізації, згідно з якою формується певна множинність фактів, які відрізняються від 
первинного джерела, наштовхує нас на думку про множинність/нескінченність віртуальних реальностей, конструйованих ЗМК, що проілюстровані на Рис. 1.

\section{МНОЖИННІСТЬ/НЕСКІНЧЕННІСТЬ ВІРТУАЛЬНИХ РЕАЛЬНОСТЕЙ ЗМК: ФАКТ-1 $\rightarrow$ ФАКТ-2 $\rightarrow$ ФАКT -3 $\rightarrow$ ФАКT-4 $\rightarrow \ldots \infty$,}

Рис. 1.

коли поняття «нескінченність» $(\infty)$ (+ чи -) визначається за загальною тональністю фактів (позитивних чи негативних). Відмінність журналістики та масової комунікації М. Житарюк вбачає у різниці феноменів: феномен масової комунікації ширший, аніж феномен журналістики, хоча зароджений в її надрах. Досить вдало у монографії М. Житарюкаподані поняття «політичного дисонансу» на прикладі «кольорові - кольорові», соціокультурні моделі, які описані та проаналізовані автором, проілюстрована система журналістикипубліцистики і національна модель журналістики. У статті М.Житарюка «Проблемні аспекти моделей журналістики» подано ключові і базові поняття «журналізм», «журналістика», де перше поняття визначено як тип, спосіб діяльності, інформаційне комунікування, а друге поняття як соціальну систему, покликану шукати, переробляти, передавати актуальну соціальну інформацію (Zhytariuk, 2007, p. 57). Дослідник поглиблює запропоновані В. Шклярем поняття дуальних домінант, подає моделі журналістики як бінарні опоненти. Можна погодитися 3 М. Житарюком, що впровадження світоглядної публіцистики як головної моделі у сучасній журналістиці неповне. Потрібно підняти на належний рівень національну журналістику та дбати про опінієтворчу публіцистику. Професійність, відповідальність за слово головний критерій роботи аналітичного журналіста, точність - інформаційного журналіста. Спосіб подачі фактів в інформаційній журналістиці низький. На нашу думку, створення «журналістики думання» як особливої моделі журналістської творчості була б противагою острівній моделі. «Журналістика думання» повинна успішно втілювати комбінацію «преса-влада-суспільство».

Серед головних парадигм, ідеологічних і філософських домінант розвитку сучасної журналістики переважає позитивістський підхід (Lylo, 2006): селекціонізм новин, ринок ідей працює як попит і пропозиція, зло продається краще (Lillo, 2006). Позитивізм у журналістиці формує негативну картину світу, далеку від реальності. Журналістам простіше написати про сенсацію із життя відомої зірки, аніж про проблеми мізерних пенсій в Україні, розкрадання майна, допомоги хворим дітям. «Журналістика думання» повинна ставити важливу соціальну чи суспільну проблему. Тоді преса впливатиме на владу, а влада змушена буде прислухатися до суспільства. Активне функціонування «журналістики думання» важливе для локальних спільнот, які завдяки ЗМІ 
могли б підвищувати загальну та політичну культуру регіональних мешканців. «Журналістика думання» наближається до континентальної журналістики, але адаптована до світоглядно-ментальних особливостей національного характеру і традицій. «Журналістика думання» мала б поєднувати в собі інформаційну, аналітичну та спеціалізовану журналістику (екологічну, економічну), в якій журналісти орієнтувалися б не на сенсаційність, а на поставлену гостру соціальну проблему, сприяли вирішенню і ухваленню політичних рішень. «Журналістика думання» повинна бути особливою сферою журналістської творчості, коли журналіст не просто інформує, розважає, а в першу чергу мислить практично і критично.

Успішний і продуктивний розвиток української журналістики, пошук своєї національної моделі, вбачаємо у поєднанні опінієтворчої, національної, світоглядної публіцистики як потужного генератора ідей, вишколу духовності, величі духу (М. Шлемкевич) та «журналістики думання» (інформаційної, аналітичної, спеціалізованої - екологічної, економічної). У функціонуванні національної журналістики України не можна залишити поза увагою публіцистику (опінієтворчу, національну, світоглядну), яка в Україні має давні традиції. Використання тільки світоглядної публіцистики як моделі національної журналістики неповне, тому що журналістика втратить свій статус суспільного, соціального інституту і професії як такої, перетворюючись на опінієтворче середовища інтелектуалів-публіцистів. У національному тілі журналістики опінієтворча, національна і світоглядна публіцистики - мозок, серце і душа, а «журналістика думання» - руки і ноги. Професіоналізм сучасного українського журналіста повинен втілюватися у схемі, де важливим чинником загальної культури та політичної культури журналіста виступають такі категорії: духовність, моральність, патріотизм у чисельнику та професіоналізм і відповідальність у знаменнику:

\section{Духовність + моральність + патріотизм}

\section{Високий професіоналізм + відповідальність.}

\section{Рис. 2}

Духовність і моральність у цій формулі різні категорії. До категорії моральності зараховуємо такі риси журналістської особистості: чесність, порядність, повага до опонентів. До категорії духовності зараховуємо віру і традиції. Журналіст повинен бути патріотом своєї держави. Поряд з тим, журналіст має мати добру базу знань і відповідати за своє слово перед громадськістю. Сьогодні ці формули наближені до нездійсненного ідеалу. Сенсаційність, позитивізм, негативізм - негласні принципи журналістики. Тому Засоби масової комунікації, зокрема журналістика, не $є$ ефективним 
захисником національних прав та інтересів нації, адже інформаційний простір незахищений на державному рівні.

\section{Висновки}

Засоби масової комунікації, зокрема Інтернет-журналістика, дають великі можливості поінформованості та пізнання, та поряд з тим, є великою загрозою для особи, держави, суспільства, оскільки далека від ідеальної моделі. Журналісти стикаються із порушенням етичних норм в Інтернеті, а також із загрозою для особи, суспільства, нації на рівні свідомісному та підсвідомості (рівень зомбування). Інтернет-журналістика як форма соціальної комунікації тільки формується, проте її вплив на сучасну людину вагомий. На жаль, запропонована наша модель національної журналістики для Засобів масової комунікації, Інтернет-журналістики зокрема, $\epsilon$ ідеалом, до якого потрібно прагнути задля безпеки: особи, суспільства, нації.

Унаслідок російсько-української війни модель Засобів масової комунікації, зокрема національної журналістики варто удосконалювати, адже від інформаційної безпеки залежить безпека держави і нації. Кіберзлочинність у Павутині ведеться на усіх рівнях: від особистісного спілкування до загрози національній безпеці, що відчуваємо під час російсько-української війни. Тому варто впроваджувати політику національної безпеки, серед важливих складових якої займатиме інформаційна кібербезпека України.

\section{References:}

1. Buriak, V. (2009). Communication and textual discourse. State and regions, Vol. 2, pp. 1-5.

2. Karpa, I. B. (2009). Language and Internet: Functional Characteristics and Effectiveness of Interactive Communication. Language and culture, Vol. 11, T. VII (119), pp. 192-200.

3. Kolesnik, O. M. (2010). Internet journalism in the light of media research. Naukovyi visnyk Skhidnoievropeiskoho natsionalnoho universytetu imeni Lesi Ukrainky [Scientific Bulletin of Volyn National University named after Lesya Ukrainka], Vol. 21, pp. 122-124.

4. Kvit, S. M. (2008). Masovi komunikatsii [Mass communication]. Kyiv: Kyievo-Mohylianska akademiia Publishing House.

5. Lylo, T.Y. (2006). Ideolohemy suchasnoi zhurnalistyky: teoriia i praktyka (chy mozhlyve svitotvorennia poza svitohliadnym kontekstom?) [Ideologems of modern journalism: theory and practice (is creation of world autside of world outlook context possible?)]. Visnyk Lvivskoho universytetu. Seriia zhurnalistyka [Bulletin of the University of Lviv. Journalism Series], issue 28, pp. 10-14. DOI: http://dx.doi.org/10.30970/vjo.2006.28.3710. 
6. Markova, G. E. (2007). Public and informational participation in public life (to definitions of concepts). Scientific notes of Taurida Vernadsky National University. Philology Series, Vol. 20, pp. 335-339.

7. Pavlyukh, M.V. (2002). INTERNET: nebezpechna virtualna realnist [Internet: dangerous virtual reality]. Day.kyiv.ua: [online].

8. Pocheptsov, H.H. (2001). Teoryia kommunykatsyy [Communication Theory]. Kyiv: Vakler; Moscow: Refl-buk.

9. Zernetskaya, O.V. (2000). Novostiinye media v politicheskom diskurse [News media in the political discourse]. Metodologiya issledovanii politicheskogo diskursa: aktual'nye problemy soderzhatel'nogo analiza obshchestvenno-politicheskikh tekstov [Methodology for the study of political discourse: actual problems of a meaningful analysis of socio-political texts], issue 2, pp. 137-145.

10. Zhytariuk, M. H. (2007). Problemni aspekty modelei zhurnalistyky [Problematic aspects of journalism models[. Visnyk Lvivskoho universytetu. Seriia zhurnalistyka [Bulletin of the University of Lviv. Journalism Series], issue 30, pp. 51-61.

11. Zhytariuk, M. G. (2008). Sotsiokulturna model zhurnalistyky: tradytsii $i$ novatorstvo [Sociocultural Model of Journalism: Traditions and Innovation]. Lviv.

(C) Павлюх М. В., 2020 